\section{Ääniä maahanmuutosta ja pakolaisuudesta}

Lyytinen, Eveliina (toim.) (2019). Turvapaikanhaku ja pakolaisuus Suomessa. Siirtolaisuusinstituutti. 349 sivua.

AJANKOHTAISET maailmanlaajuiset ilmiöt, kuten poliittiset selkkaukset ja väestön liikkuvuus maanosasta toiseen, koskettavat Suomeakin. Median välittämä kuva maahanmuutosta on usein asenteellinen ja puutteellinen. Tutkitulle tiedolle on selkeä tarve, joka - perustehtävänsä mukaisesti - lisää yhteiskunnallista sivistystä ja edistää laaja-alaista ymmärtämystä ilmiöistä.

Turvapaikanhaku ja pakolaisuus Suomessa on ajankohtainen, monitieteinen analyysi maahanmuutosta ja maahanmuuttajuudesta. Artikkelikokoelmassa 25 alan asiantuntijaa käsittelee tutkimuksen pohjalta muun muassa pakolaiseksi joutumista, Suomeen tuloa ja turvapaikanhakuprosessia. Teos tarjoaa päivitetyn, tutkimuspohjaisen tiedon nykytilanteesta ja kokoaa ilmiötä koskevat kysymykset johdonmukaiseksi ja laaja-alaiseksi kokonaisuudeksi.

Teemoja lähestytään sekä yhteiskunnallisena että yksilöllisenä prosessina: Mitä pakolaisuus on historiallisessa, poliittisessa ja lainsäädännöllisessä kontekstissa? Millaisia yksilön sosiaalisia ja inhimillisiä tarpeita yhteiskunnallisessa kotoutumisprosessissa ilmenee?

Teoksessa saavat äänen sekä turvapaikanhakijat että heidän kanssaan toimivat hallintoviranomaiset ja vastaanottokeskusten naapurit. Teoreettisena taustana ovat ajalliset ja tilalliset muutokset turvapaikanhakuprosessin ja kotoutumisen eri vaiheissa ja oloissa.

\section{TEOS ALANSA}

TUTKIMUSKONTEKSTISSA

Teoksessa rakennetaan perusta ja aikaperspektiivi Suomen humanitäärisen avun kansalliselle historialle. Humanitäärisen avun myötä yhteiskunnallinen yhdenvertaisuus ja moniarvoisuus ovat maassa kehittyneet. Lukijalle konkretisoituu, miten pakolaisuus käsitteenä ja pakolaisuuden luonne ovat muuttuneet vuosikymmenien aikana.

Pakolaistutkimusta tehdään Suomessa eri tieteenaloilla ja lukuisissa tutkimushankkeissa ja -laitoksissa. Sitä tekevät niin humanistit kuin yhteiskuntatieteilijätkin - kulttuurintutkijat, oikeustieteilijät, sosiologit, antropologit ja maantieteilijät. Pakolaisuus onkin ilmiönä hyvin monialainen.

Perustellusti on todettava, että Suomessa 1990-luvulta vuoteen 2004 tehdyn muuttoliike- ja etnisyystutkimuksen analyysin perusteella lähes kaikkea on jo tutkittu. Sen sijaan muuttoliikkeitä ja etnisiä kysymyksiä koskeva teoreettinen tutkimus on ollut vähäistä empiiristen tapaustutkimusten rinnalla. Teos vastaa tarpeeseen koota ja yhtenäistää pakolaisia

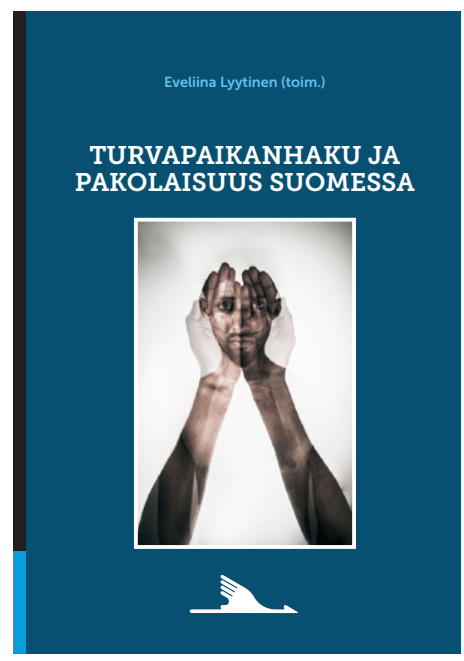

koskevaa tutkimusta ja päivittää nykyistä pakolaistilannetta.

MAAHANMUUTTOPOLIITTINEN ASENNEMUUTOS SUOMESSA OSANA KANSAINVÄLISTÄ YHTEISTYÖKEHITYSTÄ

Historiallisesti turvapaikan myöntämisen perusteet ovat Suomessa olleet tiukat ja maahanpääsy vaikeaa. Käsitteet 'maasta käännyttäminen' ja 'karkottaminen' kirjattiin ulkomaalaisasetukseen vuonna 1958, jolloin asetuksen nojalla tehtyjä viranomaispäätöksiä ei tarvinnut perustella, eikä muutoksenhakuoikeutta ollut.

1980-luvulla Pohjoismaiden neuvoston aloitteesta Suomi lisäsi kansainvälistä yhteistyötä pakolaiskysymyksissä. Eduskunnassa asiaa vastustettiin aluksi, koska sitä pidettiin neuvostossa käsiteltävien aiheiden ulkopuolisena. Todettiin, että pakolaiskysymys koskettaa "maan kansainvälisiä suhteita ja ulkopolitiikkaa siinä määrin, ettei sitä pitäisi ottaa mukaan pohjoismaiseen yhteistyöhön. Kunkin maan tulee itse 
ratkaista, missä määrin se on valmis ottamaan vastaan pakolaisia”.

Suomessa pirstaleiset ja poliittisesti lyhytnäköiset kannanotot koettiin kuitenkin ongelmalliseksi, ja hallitusohjelmaan ensimmäiset maahanmuuttopoliittiset periaatteet kirjattiin vuonna 1995. Samana vuonna Suomi liittyi Euroopan unioniin. Valtioneuvosto ohjeisti Suomen ottamaan vastaan kiintiöpakolaisia ja turvapaikanhakijoita kansainvälisten sopimusten edellyttämällä tavalla, ihmisoikeuksia kunnioittaen ja järjestelmän väärinkäytöksiä estäen. Turvapaikkapäätöksiin oli mahdollista hakea muutosta oikeushallinnon eri asteilta.

Turvapaikanhaku ja pakolaisuus Suomessa havainnollistaa sen, kuinka poliittiset ratkaisut ovat ohjanneet maahanmuuttoa koskevia päätöksiä. Puolueet käsittelivät poliittisissa ohjelmissaan pakolaiskysymystä 1980-luvulla ulkopolitiikan ja kehitysyhteistyön osana, mutta 1990-luvulla pakolaispolitiikka liitettiin jo osaksi sisäpolitiikkaa, jolloin turvapaikkakysymykset syrjäyttivät puolueiden ja hallitusten kannanotoissa kiintiöpakolaispolitiikan ja kehitysyhteistyön kysymykset.

Vuonna 1999 tuli voimaan ensimmäinen kotouttamislaki, jonka myötä maahanmuuttajia ryhdyttiin pitämään omana ryhmänään. Kansainvälistä suojelua tarvitsevat tulivat osaksi yleisiä kotouttamistoimenpiteitä, jotka koskivat muun muassa työelämään pääsyä, henkilökohtaisen kotoutumissuunnitelman laatimista, mahdollisuuksia kielen oppimiseen ja oikeutta omaan kieleen ja kulttuuriin. Laissa säädettiin lisäksi useista turva- paikanhakijoiden vastaanottoa koskeneista käytänteistä.

Kotouttamislain uudistuksessa vuonna 2010 otettiin huomioon eri turvapaikanhakijaryhmien, kuten naisten ja yksintulleiden alaikäisten lasten tarpeet ja painotettiin henkilökohtaisten kotoutumissuunnitelmien laatimista kunnissa. Kansainvälistä suojelua saavia koskeneet periaatteet pysyivät kuitenkin ennallaan vuoden 1999 kotouttamislain mukaisesti.

Turvapaikka- ja pakolaispoliittista keskustelua kuumensi vuosien 2015-2016 pakolaiskriisin aiheuttama poikkeuksellinen turvapaikkatilanne. Sen jälkeen lainsäädäntöön tehtiin ulkomaalaisten ja turvapaikanhakijoiden oikeusturvaa heikentäviä muutoksia.

Nykyistä sisä- ja ulkomaalaispolitiikkaa koskevaa keskustelua säätelevät yhteiskunnallisen talouden kestävyys ja kansainväliset yhteistyösopimukset. Taloudelle ja yksilölle keskeistä työllistämistä kotoutumisen osana käsitellään teoksessa kuitenkin yllättävän vähän. Myös koulutuksen näkökulma ja ilmastonmuutoksen vaikutukset väestön liikkuvuuteen sivuutetaan kokonaan.

\section{PAKOLAISUUS KARTTANA INHIMILLISEEN ASENNOITUMISEEN}

Poliittisten prosessien ja hallinnollisten rakenteiden lisäksi teos kuvaa vastaanottokeskuksia: asiakkaita, henkilöstöä ja ympäristössä asuvia ihmisiä. Suomalaiset vastaanottokeskukset edustavat teoreettisesti Giorgio Agambenin (2001) ja
Shahram Khosravin (2013) mukaan poikkeuksen tiloja, joissa turvapaikanhakijoiden elämä "asettuu sulkeisiin”. Keskusten asukkaat on ikään kuin asetettu hiljennettyyn ja passiiviseen identiteettiin, joka ei juuri saa omaa ääntään kuuluviin vaan jää pikemminkin erilaisten toimenpiteiden kohteeksi.

Vastaanottokeskukset ovat siten välitiloja, joissa ihminen on matkalla varsinaiseen päämääräänsä: pysyvään oleskeluoikeuteen maan täysivaltaiseksi asukkaaksi. Mitä itsenäisemmin hakijat pystyvät elämään, sitä suurempi hallinnan tunne heillä elämäänsä on.

Lukija saa runsaasti tietoa hallinnollisesta turvapaikanhakuprosessista ja pakolaisten kokemuksista maahanmuuton alkuvaiheissa. Inhimillisen kärsimyksen kokemusten kuvaaminen maahanmuuttoprosessin ajallisissa ja tilallisissa konteksteissa avaa mahdollisuuden ymmärtää ilmiötä syvällisesti.

Teoksen tapa käsitellä pakolaisuutta on samalla sekä objektiivinen että subjektiivinen kokonaisuus. Se voi todella muuttaa lukijan asennoitumista maahanmuuttajuuteen ilmiönä. Jos näin käy, teoksen tavoite edistää maahanmuuttoa koskevia asenteita ihmisoikeuksia kunnioittavampaan suuntaan toteutuu, mikä lienee perustellusti teoksen vahvin anti.

TARJA LANG

FT, MBA, tutkimuspäällikkö Omnia, Espoon seudun koulutuskuntayhtymä

\section{ANITA HIETALAHTI}

FM, lehtori, projektitutkija Omnia, Espoon seudun koulutuskuntayhtymäia 